\title{
Alison Ohta, J.M. Rogers, Rosalind Wade Haddon (eds.). Art, Trade and Culture in the Islamic World and Beyond. From the Fatimids to the Mughals. Studies Presented to Doris Behrens-Abouseif
}

\section{Iván Szántó}

\section{OpenEdition}

\section{Journals}

Electronic version

URL: http://journals.openedition.org/abstractairanica/43202

DOI: $10.4000 /$ abstractairanica.43202

ISBN: 1961-960X

ISSN: 1961-960X

Publisher:

CNRS (UMR 7528 Mondes iraniens et indiens), Éditions de l'IFRI

Electronic reference

Iván Szántó, « Alison Ohta, J.M. Rogers, Rosalind Wade Haddon (eds.). Art, Trade and Culture in the Islamic World and Beyond. From the Fatimids to the Mughals. Studies Presented to Doris Behrens-Abouseif ", Abstracta Iranica [Online], Volume 37-38-39 | 2018, document 11, Online since 30 December 2018, connection on 28 September 2020. URL : http://journals.openedition.org/abstractairanica/43202 ; DOI : https://doi.org/10.4000/abstractairanica.43202

This text was automatically generated on 28 September 2020.

Tous droits réservés 


\title{
Alison Ohta, J.M. Rogers, Rosalind Wade Haddon (eds.). Art, Trade and Culture in the Islamic World and Beyond. From the Fatimids to the Mughals. Studies Presented to Doris Behrens-Abouseif
}

\author{
Iván Szántó
}

\section{REFERENCES}

Alison Ohta, J.M. Rogers, Rosalind Wade Haddon (eds.). Art, Trade and Culture in the Islamic World and Beyond. From the Fatimids to the Mughals. Studies Presented to Doris Behrens-Abouseif. London: Ginkgo Press, 2016, 282 p., ISBN: 9781909942-90-5

1 With subjects ranging from mediaeval metalwork to early 20th-century architecture and a geographic horizon spanning between Europe and China, the essays in this volume reflect not only the multifarious scholarly interests of its dedicate but also the variety of phenomena which has been defined by western academia as Islamic art. On the other hand, despite studies about Mughal painting or European lacquer, the book is dominated by studies about the core subject of Doris Behrens-Abouseif, namely architecture and architectural decoration, as well as the core geography of her scholarly pursuits, the eastern Mediterranean, and within it Mamluk Egypt. In addition, the authors envisioned an underlying theme throughout the volume, i.e., "the transfer of ornament and techniques associated with certain media over long periods of time and distances." 
2 The 23 articles are divided into five, taxonomically defined, parts: metalwork, architecture, ceramics, book arts/painting, and "material culture". These are preceded by two forewords by Nasser D. Khalili and the editors, respectively, and a bibliography of Doris Behrens-Abouseif (up to 2014).

3 The series of four chapters about metalwork opens with Moya Carey's essay about a brass object in the Victoria and Albert Museum showing characteristics of the art of Mosul during its foremost 13th-century ruler, Badr al-Din Lu'lu' (“Traces of Mosul: An Inlaid Brass Pen Box in the V\&A", pp. 18-25), followed by a study by Nikolaos Vryzidis on cross-cultural interaction between Mamluk and (post-)Byzantine art, through the example of a Mamluk brass lamp in the monastery of St. John in Patmos ("The Second Life of a Mamluk Lamp from Saint John the Theologian Monastery, Patmos and the Oral Tradition Attached to It", pp. 26-35). Cultural transfer and Mamluk metalwork stay in the focus of the next chapter ("Mean or Green? Mamluk Vessels Recycled for the Rasulid Sultans", pp. 36-48) in which Rachel Ward analyses three different brass objects and identifies Mamluk patrons' names under the current Rasulid ones, leading her to the conclusion that these "palimpsests" were recycled by the Mamluks to send them as diplomatic gifts to their vassals in Yemen.

Co-authored by Bernard O'Kane and Bahia Shehab, the first essay of the section about architecture ("The Mausoleum of Yahya al-Shabih Revisited", pp. 50-57) reconsiders a Cairene mausoleum and by having a careful look at its foundation inscription, it gives a much more precise context for its epigraphy, dating, and patrons. Based on textual sources, "A Tale of Two Ceilings: The Cappella Palatina in Palermo and Mouchroutas in Constantinople" (pp. 58-73), by Jeremy Johns, suggests that the still extant ceiling in Palermo and the vanished one in Constantinople may have been the work of the same Fatimid workshop, despite the frequent reference by the main Byzantine source to "Persian hands". The transfer of architectural ideas is the major topic of Helen Philon's article ("Mahmud Gawan's Madrasa in Bidar: A Unique Architectural Transplant from the Timurid World to the Deccan", pp. 74-85) in which a building which shows the mid-15th-century innovations by the master builder Qawam al-Din Shirazi is explored along with the intellectual backround and motivations of its patron. A MamlukOttoman trajectory is pursued by Bora Keskiner, in her study about inscriptions in a 14th-century madrasa in Tripoli and Istanbul's much more recent, emblematic mosque ("The Octagonal Kufic Inscription in the Qartawiyya Madrasa and its Counterpart in the Sultan Ahmed Mosque"). In "Victory in the Making: The Symbolism of Istanbul's Nusretiye Mosque" (pp. 92-115), Ünver Rüstem argues on the basis of archival records that the mosque (completed in 1826), the first significant surviving monument of the Balian dynasty of architects, served to herald the military reforms of Sultan Mahmud II that were to come just after the inauguration of the building, starting with the eradication of the janissaries. The next article ("Mehmet Baha Tanman: The Spiritual and Mystical Dimensions of the Hamam in Turkish Bathing Culture", pp. 116-123) takes a generalising approach to architecture, investigates the hamam from a Sufi point of view, and examines the spatial arrangement of baths in külliyes and tekke-complexes. The title of "I Understood that he is Entrusted to Serve Some Great Business Undertaking': Armenian Architects Reshaping the Ottoman East in the Hamidian Era (1876-1909)" by Alyson Wharton-Durgaryan (pp. 124-138) refers to Joseph Elias, a highly esteemed Armenian Catholic architect in late-Ottoman Lebanon, who was a 
representative of an entire class of professionals that played a hitherto littleunderstood role in the last urban renewal of the Ottoman eastern provinces.

Part three begins with "The Shelf Life of Port Saint Symeon Ceramics: Evidence from Kinet Höyük" by Scott Redford (pp. 140-149), aiming to shed light on the local usage of a type of 13th-/early 14th-century Eastern Mediterranean ceramics which was generally considered to be an export ware. Rosalind Wade Haddon's essay ("Trade and Innovation Seen through Mamluk, Ilkhanid and Golden Horde Imitation Celadon Wares", pp. 150-158) seeks to reconstruct the circumstances under which Lonquan wares became one of the most sought-after commodities from China in West Asia and which not only triggered trade but also widespread imitation. Moving on to the turn of the 16th century, Sami de Giosa ("Decorative Tiles in Egypt and Greater Syria during the Reign of Sultan Qaitbay [r. 1468-1496]", pp.159-167) examines the reasons and consequences of the final efflorescence of tile decoration in Egypt and Greater Syria which put an end to fifty years of stagnation and lasted until the end of the Mamluk Empire in 1517. Representations of women were rare in 16th-century Ottoman book painting, let alone ceramics, making the examples, analysed by Filiz Yenişehiroğlu ("Representations of Lyrical Beauty: The Image of a Courtesan at the Topkapi Palace in the Seventeenth Century", pp.168-175), distinctive. The global presence and robust international patronage of Armenian merchants are the theme of "Armenian Patrons for Chinese Commodities: Trade Networks and Cultural Exchange across Asia" by George Manginis (pp.176-187) which investigates the engagement of Armenians with Chinese porcelains from the 17th to the 19th centuries in Iran, India, and Turkey. The short-lived fashion of Ottoman-inspired late-19th-century British tiles, marketed as Persian, are surveyed by Melanie Gibson in 'Colouring the Surface: A Taste for 'Persian' Tiles in English Domestic Architecture, 1870-1914" (pp. 188-201).

Dealing with book arts and painting, part four begins with Mehreen Chida-Razvi's "A Sultan before the Padshah? Questioning the Identification of the Turbaned Figure in Jahangir Preferring a Sufi Shaykh to Kings" (pp. 204-223) which suggests that a particular figure long identified as an Ottoman Sultan may be a Christian cleric or a Russian instead. "The Bindings of Qansuh al-Ghawri" by Alison Ohta (pp. 215-224) serves as an appendix to an essay by Doris Behrens-Abouseif about the art patronage of the penultimate Mamluk sultan. The next article (J. M. Rogers: “'A Sacred Tree': A Paper Collage in the Khalili Collection", pp. 225-231) situates a Deccani cut-out work in a South Asia/Iran/Portugal cross-cultural triangle. Through depictions of a ruler previously marginalised by art historians, Malini Roy's "Historical Portraits of Mughal Emperor Aurangzeb 'Alamgir I (r. 1658-1707)" (pp. 232-239) reassesses the role of painting and paintings in his court.

7 Part five gathers together three articles under the umbrella of 'minor arts'. Javad Golmohammadi in "The Art of Iranian Decorative Veneer, Khātam-kāri" (pp. 242-253) traces back this technique to the 14th century and offers a general survey in which the versatility of marquetry is demonstrated. "Swimming across the Weft: Fish Motifs on Mamluk Textiles" (Maria Sardi, pp. 254-263) draws attention not only to the significance of this motif, but also to its Iranian and Chinese prototypes. Finally, Tim Stanley untangles the apparently parallel development of Russian and Iranian lacquer pen boxes in the 19th century, both made for the Iranian market, and concludes that the former relied on French models which were, in turn, originally inspired by the 
Mediaeval Iranian concept of lacquerwork ("Double Orientalism: Persian Lacquer and Its Unacknowledged Debt to Iran", pp. 264-276).

\section{AUTHORS}

\section{IVÁN SZÁNTÓ}

Eötvös Loránd University, Budapest \& Austrian Academy of Sciences, Vienne 